Gut, 1968, 9, 46-47

\title{
Treatment of gastric ulcer with oestrogens
}

\author{
RICHARD DOLL, M. J. S. LANGMAN, AND H. H. SHAWDON \\ From the Medical Research Council's Statistical and Gastroenterological Research Units and the \\ Department of Radiology, Central Middlesex Hospital, London
}

When Truelove (1960) reported that oestrogens, in the form of stilboestrol, helped to heal duodenal ulcers, evidence of their value began to be sought in the Gastroenterological Department at the Central Middlesex Hospital (Connell, Fletcher, Jones, Langman, Lennard-Jones, and Pygott, 1966). The effect of oestrogens on patients with gastric ulcers was also examined, and in 1965 Doll, Hill, and Hutton reported the results of a controlled trial in which a small number of patients were given either stilboestrol or dummy tablets. Men were given $1 \mathrm{mg}$ of stilboestrol a day (the same dose as had been used by Truelove) and women who had passed the menopause were given oestrol $1 \mathrm{mg}$ a day. On average, the amount of healing (expressed as the percentage reduction in the initial size of the ulcer in five weeks) was greater in the oestrogen group than in the control group, but the numbers were small, the difference was not statistically significant and this result could not be regarded as conclusive. The opportunity was, therefore, taken to make further observations during a trial of new methods of treatment with carbenoxolone sodium.

\section{METHOD}

Stilboestrol $0.5 \mathrm{mg}$ or an apparently identical dummy tablet was given twice a day for four weeks to 32 male patients with gastric ulcers. The patients also received treatment with carbenoxolone sodium in doses of 150 to $300 \mathrm{mg}$ a day combined with two different diuretic regimes. The oestrogen and dummy tablets were, therefore, given in random order, but with the restriction that each type of tablet was given an equal number of times with each combination of carbenoxolone dose and diuretic regime. To avoid bias in the assessment of the results no one concerned with the trial, apart from the hospital pharmacist, knew the identity of the tablets given to each patient until the investigation was finished. Details of the selection of patients, the method of conducting the trial, and the other treatments are given elsewhere (Doll, Langman, and Shawdon, 1968).

RESULTS

The effect of treatment was assessed by measuring the change in size of the ulcer niche. The results, summarized in Table I, show that the proportion of patients in whom the ulcer healed completely was less in those given stilboestrol (four out of 16) than in those given dummy tablets (eight out of 16), but that the average reduction in the size of the niche was greater in the patients given stilboestrol. Measured as a percentage of the initial size of the ulcer the average reduction in the two groups was respectively $64 \%$ and $55 \%$. Neither of these differences is statistically significant; in each case the probability of obtaining as large a difference or larger by chance is more than $10 \%$ (exact test of the difference between the proportions healed and a ranking test of the change in size of the ulcer niches).

TABLE I

RESULTS OF TREATMENT: CHANGE IN SIZE OF ULCER NICHE IN FIVE WEEKS

\begin{tabular}{|c|c|c|c|c|}
\hline \multirow[t]{2}{*}{$\begin{array}{l}\text { Specific } \\
\text { Treatment }\end{array}$} & \multirow[t]{2}{*}{$\begin{array}{l}\text { No. of } \\
\text { Patients }\end{array}$} & \multirow{2}{*}{$\begin{array}{l}\text { No. in whom } \\
\text { Ulcer } \\
\text { Healed }\end{array}$} & \multicolumn{2}{|c|}{$\begin{array}{l}\text { Average Reduction in } \\
\text { Size of Ulcer }\end{array}$} \\
\hline & & & $\begin{array}{l}\text { Percentage } \\
\text { of Initial } \\
\text { Size }\end{array}$ & $\begin{array}{l}\text { Percentage } \\
\text { of Mean } \\
\text { Size }\end{array}$ \\
\hline $\begin{array}{l}\text { Stilboestrol } \\
\text { Dummy tablets }\end{array}$ & $\begin{array}{l}16 \\
16\end{array}$ & $\begin{array}{l}4 \\
8\end{array}$ & $\begin{array}{l}\text { Size } \\
64 \cdot 3 \\
55 \cdot 2\end{array}$ & $\begin{array}{l}\text { Size } \\
114 \cdot 3 \\
120 \cdot 4\end{array}$ \\
\hline
\end{tabular}

The paradoxical observation that the results obtained by the two methods of assessment appeared to point in different directions can be attributed to the fact that two of the patients given dummy tablets had small ulcers initially which became larger. The change in ulcer size, measured as a percentage of the initial size, was, therefore, also large $(+98 \%$ and $+114 \%$ respectively) and these two results weighed heavily in the estimate of the average changes for the whole group. If, alternatively, the change in the ulcer had been expressed as a percentage of its mean size at the beginning and at the end of treatment, the two extreme results would have carried less weight and the average reduction for the group would have been slightly greater for the controls $(120 \%)$ than for those given stilboestrol $(114 \%)$. 
This change in base line, it may be noted, would not affect the ranking of the observations and therefore the statistical significance of the results obtained would be unaltered.

Table II shows that there were no marked differences between the patients in the two treatment groups in respect of their age or smoking habits, but there was a marked inequality in the proportions of ulcers initially 50 to $99 \mathrm{sq} \mathrm{mm}$ in area and $100 \mathrm{sq} \mathrm{mm}$ and over. From the experience of previous trials (Doll and Langman, unpublished data), this inequality would have tended to decrease the probability of obtaining complete healing of the ulcer within five weeks in the patients given stilboestrol, but it would have very little effect on the average percentage reduction in the size of the ulcer.

\section{TABLE II}

COMPARABILITY OF PATIENTS IN THE TWO TREATMENT GROUPS

\begin{tabular}{|c|c|c|}
\hline \multirow[t]{2}{*}{ Characteristic } & \multicolumn{2}{|c|}{ No. of Patients Given } \\
\hline & Stilb & $\begin{array}{l}\text { Dummy } \\
\text { Tablets }\end{array}$ \\
\hline
\end{tabular}

No patients complained of symptoms which could be attributable to the use of stilboestrol during the course of treatment, but three patients who had been given stilboestrol complained of tenderness in the breast a few days after treatment had been stopped. It should be noted that direct questions about loss of libido were (intentionally) not asked.

\section{SUMMARY AND CONCLUSIONS}

The effect of oestrogens on the healing of gastric ulcers has been assessed in a small 'double-blind' controlled trial. Stilboestrol $0.5 \mathrm{mg}$, or an apparently identical dummy tablet, was given twice a day for four weeks to 32 male patients. Patients were allocated to the treatment groups by a form of restricted randomization and the results were assessed by measuring the change in the size of the ulcer, without knowledge of which treatment the patient had received.

The difference between the results in the two groups was small and did not suggest that any benefit could be attributed to the use of the drug.

\section{REFERENCES}

Connell, A. M., Fletcher, J., Jones, J. H., Langman, M. J. S., LennardJones, J. E., and Pygott, F. (1966). Oestrogens and high-protein and high-carbohydrate diets in the treatment of duodenal ulcer. Gut, 7, 717

Doll, R., Hill, I. D., and Hutton, C. F. (1965). Treatment of gastric ulcer with carbenoxolone sodium and oestrogens. Gut, 6, 19-24.

- - Langman, M. J. S., and Shawdon, H. H. (1968). Treatment of gastric ulcer with carbenoxolone: antagonistic effect of spironolactone. Gut, 9, 42-45. Non-smoker, continued

Smoker, stopped

Smoker, reduced by half or more

Smoker, other
Truelove, S. C. (1960). Stilboestrol, phenobarbitone and diet in chronic duodenal ulcer. Brit. med. J., 2, 559-566. 